\title{
Fiscal Decentralization Effect on Financial Performance: Mediated by Size and Moderated by Audit Opinion in Lampung Province
}

\author{
Eka Ningsih Puji Rahayu${ }^{1}$, Rudy Badrudin ${ }^{2} \bowtie$ \\ ${ }^{1}$ Akademi Akuntansi Lampung \\ ${ }^{2}$ Sekolah Tinggi Ilmu Ekonomi YKPN Yogyakarta \\ e-mail: rudybadrudin.stieykpn@gmail.com
}

\begin{abstract}
This research aims to examine the effect of fiscal decentralization on financial performance by adding government size as the mediator variable and audit opinion as the moderator variable of counties and cities in Lampung Province. Lampung Province is the center of economic mobility in South of Sumatera Island so it can impact well to regional autonomy implementation and has the best financial statements (an unqualified opinion) in Sumatra Island (47.5\%). This research was conducted in 13 counties and 2 cities in 2010-2013 for the objective to see the regional autonomy implementation started in one decade. The examination of hypothesis used to Partial Least Square with the significant of decision-making $<0.10$. The results show that fiscal decentralization gives the positive and significant effect to financial performance but nonsignificant effect to government size; government size gives the positive and non-significant effect to finance performance; and fiscal decentralization gives the positive and non-significant effect to finance performance with the audit opinion as the moderator variable.
\end{abstract}

Keywords: decentralization, financial performance, audit opinion

\begin{abstract}
Abstrak
Penelitian ini bertujuan untuk menguji pengaruh desentralisasi fiskal terhadap kinerja keuangan dengan menambahkan ukuran pemerintah sebagai variabel mediator dan opini audit sebagai variabel moderator dari pemerintahan kabupaten dan kota di Provinsi Lampung. Provinsi Lampung dipilih sebagai obyek penelitian karena pusat mobilitas ekonomi di Pulau Sumatera bagian Selatan sehingga dapat berdampak baik bagi pelaksanaan otonomi daerah dan juga memiliki laporan keuangan terbaik (pendapat wajar tanpa pengecualian) di Pulau Sumatera (47,5\%). Penelitian ini dilakukan di 13 kabupaten dan 2 kota pada tahun 2010-2013 dengan tujuan untuk melihat implementasi otonomi daerah setelah satu dekade. Pengujian hipotesis penelitian menggunakan Partial Least Square dengan angka signifikansi $<0,10$. Hasil penelitian menunjukkan bahwa desentralisasi fiskal berpengaruh positif dan signifikan terhadap kinerja keuangan namun tidak berpengaruh signifikan terhadap ukuran pemerintah; ukuran pemerintah berpengaruh positif dan tidak signifikan terhadap kinerja keuangan; dan desentralisasi fiskal berpengaruh positif dan tidak signifikan terhadap kinerja keuangan dengan opini audit sebagai variabel moderator.
\end{abstract}

Kata kunci: desentralisasi, kinerja keuangan, opini audit 


\section{INTRODUCTION}

\section{Background Research}

Regional autonomy implemented since 2001. Speaking about regional autonomy, then do not forget to speak of fiscal decentralization that is used as the basis for the implementation of regional autonomy. The local government through fiscal decentralization is given discretion in managing local revenue to meet the needs of the autonomous region (Siregar and Badrudin, 2017).

The magnitude of what the central government on fiscal decentralization to be properly budgeted and realized well that the financial independence of a region can be realized so that all shopping needs will be met in the area also has become a common thing for some it is an indicator of financial performance area. In fact, fiscal decentralization remains a serious problem in all counties/cities in Lampung Province after a decade in the implementation of regional autonomy. During 2010-2013, fiscal decentralization in the counties/ cities in Lampung Province has a pattern of relationships instructive, whereas fiscal decentralization is an important thing that is used to determine the financial dependence on the central government. Small fiscal decentralization will greatly affect the local financial performance (effectiveness) because the form of fiscal decentralization in Indonesia focused on fiscal decentralization expenditures.

It is also fueled by a growing number of people in an area that would be a financial burden, whereas the population is an asset for the region as well, which if fulfilled needs will have a positive impact on the economy. The need for the central government to intervene in providing additional revenue by considering the amount of income each region and the many of the population will be a solution for the region because of the big size of local government will help fiscal decentralization in realizing the financial performance of quality. In addition, decentralization also make the government vulnerable to misuse of regional wealth. The need for transparency and accountability its performance will be better, so the selection of audit opinion variables can be used to strengthen the influence of fiscal decentralization on local financial performance.

\section{Research Purposes}

On the basis of research background, the purposes of this study to evaluate the implementation of regional autonomy in counties/city Lampung Province. The evaluation implementation of regional autonomy in counties/city Lampung Province through testing 1). the positive effect of fiscal decentralization on financial performance of the counties/city in Lampung Province, 2). the positive effect of fiscal decentralization on local governance size counties/cities in Lampung Province, 3). the positive effect of local government size on financial performance of the counties/ cities in Lampung Province, and 4) the positive effect of fiscal decentralization on financial performance of the audit opinion as moderating variable in the counties/cities in Lampung Province.

\section{Research Contributions}

The findings of the research will be the input for the counties/city government in Lampung Province in formulating budget policy. Based on that, the construction activity is expected to be smooth and supports the achievement of good governance government so as to improve budget managing in counties/ city Lampung Province. In addition, research findings will be useful in contributing to the development of public sector finance theory. 


\section{Literature Study}

According to Halim and Abdullah (2006), implementation decentralization attaches agency theory as a result of devolution, then automatically there will be parties to delegate powers (the principal) and no authorized parties (agent). Executives in the public sector is an agent for the legislature and the public (dual accountability) and the legislative is agent for the public. Natural thing in the agent and the principal is the discrepancy between the information. More information will be owned by the agency rather than by the principal. According to Basrie et al. (2012), the government's performance in Bandar Lampung is not maximized due to a lack of responsibility for human resources. This is evident from the achievements of the amount of expenditure which only amounted to $96.69 \%$ of the target and the amount of cash flow decline.

According to Kusumawardani (2012), the size of government and the size of the legislature affect the financial performance of local governments. It can be used as a justification of a large size can help the operations of local authorities accompanied by increased financial performance of local governments. Legislative size affect the financial performance of local governments, because the increasing number of qualified members of the legislature, the more lightweight and easy to carry out the task of their functions and roles in the supervision of the local government. Leverage does not affect the financial performance of local governments for external financing of local government not only through debt but also from the Fund Balance.

According to Dwijayanti and Rusherlistyanti (2013), there were differences in the degree of independence, effectiveness, and activity between routine and development expenditure in the provincial government's financial performance in Indonesia 20082010. However, there are differences in the level of efficiency and revenue growth rates on the financial performance of the provincial government in Indonesia 2008-2010. According to Fidelius (2013), the ratio of the effectiveness of the financial management performance of Manado is quite effective. This is demonstrated by the effectiveness of financial management performance reached $104.26 \%$ of the local budget in 2012 . However, for the performance of financial management Manado City based financial self-sufficiency ratio is still very low. That is, the relatively small contribution of revenue in the budget.

According to Manik (2013), prosperity and the size of local government a significant effect on human development. According to Sianturi et al (2013), the level of fiscal decentralization below $10 \%$. It can be seen from the ratio of revenue to the budget which in 2008 amounted to $4.56 \%$, in 2009 by $4.71 \%$, 2010 was $4.32 \%, 2011$ was $6.78 \%$, and 2012 by $7.82 \%$. This indicates that the degree of fiscal decentralization in Batu City is still lacking. According to Sularso and Restianto (2011), the financial performance APBD counties/cities in West Java Province has not been optimal. That is, the counties/ cities in West Java Province have not been effective and precise in using the budget. Therefore, budgets counties/cities in West Java Province has not resulted in increased social welfare.

According to Susanto and Badrudin (2016), the allocation of the budget so that more priority alignments for public purposes (capital expenditure) rather than the interests of personnel (personnel expenditure). In allocating the capital expenditure component must consider several things: direct capital expenditure for the construction of supporting infrastructure investment in the region in promoting economic growth in the region; an evaluation and assessment of the inventory items are available both from the state and its economic life so that the procurement of 
inventory items can be selectively carried out according to the needs of each Local Government Unit (SKPD); and make capital expenditures for the purchase price/ wake fixed assets plus all expenditures associated with procurement of fixed assets until ready to use.

Routine problems that always arise in the management of the budget is the proportion of capital spending and the rate of absorption of low capital expenditure budget. This relates to the politics of local government budgets in managing the budget. Budgets are policy instruments owned by the local government to describe a comprehensive statement about the priorities of the region and also shows the estimated performance of local governments that will be achieved during a certain period. Many counties/cities in Indonesia, which has a large portion of the budget with the allocation of indirect expenditures (personnel expenditures), while the allocation of direct expenditure (capital expenditure) is relatively low. This affects the success of development as measured by the Human Development Index. Therefore, the principle of budget management should as much as possible for the prosperity of society (Badrudin and Siregar, 2015 and Badrudin, 2015).

\section{Hypotheses Development}

Fiscal decentralization provides an opportunity for the region to explore and manage revenue. The local government will be more flexible in determining the budget of local revenue for local governments more aware of the condition of the autonomous region, so that the realization is more easily achieved (Halim and Abdullah, 2006). The participation of district Own Source Revenues are very important in the success of fiscal decentralization (Sianturi et al. 2013). After realization can be achieved, the government will reduce its dependence on the central government which is characterized by local financial independence. Fiscal decentralization also makes it easier to regulate the proportion/ conformity expenditure (the proportion of recurrent and development expenditure), so that the greater is fiscal decentralization will be the greater local financial performance (Smeru, 2002: 41 and Susanto and Badrudin, 2016). Based on these explanations, it can be arranged hypotheses:

H1: Fiscal decentralization has positive effect on local financial performance of the counties/cities in Lampung Province

Fiscal decentralization will provide flexibility for regions to dig own resource revenue, so that own resource revenue will increase and revenue of sharing fund tax and non-tax be the main source to finance the interest of the population/ public. The implication revenue (central and local) will be greater than the total population. This means that fiscal decentralization will increasingly contribute positively to the size of local government. Dwijayanti and Rusherlistyanti (2013) show that fiscal decentralization is measured using indicators of revenue and expenditure decentralization have a positive impact or increasing the size of local government at the local counties/ cities. Based on these explanations, it can be arranged hypotheses:

H2: Fiscal decentralization has positive effect on local government size of the counties/cities in Lampung Province

The regional government large size will provide added value to the area because it would be optimal in providing services to the needs of the autonomous regions, especially financial needs. It is expected that the size of the local government will have implications on the region's financial performance. It can be seen from the optimal management of potential areas in order to achieve independence, conformity and effectiveness of the underlying 
financial performance of a regional framework (Badrudin, 2015). So that the larger the size of local government, the greater the financial performance of the region. According Kusumawardani (2012), Fidelius (2013), and Malik (2013), the regional government large size be able to help the operations of the local government, accompanied by improved financial performance of local governments. Based on these explanations, it can be arranged hypotheses:

H3: Local government size has positive effect on local financial performance of the counties/cities in the Lampung Province

Fiscal decentralization in certain situations was not able to guarantee the high performance of the local goverment finance, because there is no transparency and accountability of the local government finance report. Basically, the calculation of fiscal decentralization and regional financial performance using ratios from local government finance report. if the numbers are expressed in local government financial report is not a number that should be. It is certain that the financial performance of the calculation results become inaccurate. The audit opinion from Badan Pemeriksa Keuangan (BPK) can prove through accountability and transparency local government financial report (Basrie et al., 2012). The audit opinion is expected to strengthen the effect of fiscal decentralization on local financial performance, so the better the audit opinion (unqualified opinion) will have good implications and strengthen the effect of fiscal decentralization on local financial performance. Based on these explanations, it can be arranged hypotheses:

H4: Fiscal decentralization has positive effect on local financial performance of counties/cities in Lampung Province with audit opinion as moderating variables.

\section{METHOD}

\section{Research Design}

The design of this research is explanatory, the research was designed through the stages of collecting the necessary data, the determination of the analytical tools used, and the analysis of the data used.

\section{Research Samples}

The population selected in this study were all counties/cities in Lampung Province during the period 2010-2013 which amounted to 13 counties and 2 cities. The sample used in this study is the counties/cities that has full terms of data to be sampled. Pesisir Barat Counties does not qualify as samples, because formed in 2012, so that the sample used in this study were 12 counties and 2 cities in Lampung Province.

\section{Data Collection Technique}

Secondary data in this study is financial data and data non-financial. The financial data is data regional government budget and the realization of the regional government budget that displays data is fiscal decentralization, local financial performance, local revenue and income that comes from the center. Non-financial data is data of the population and the audit opinion given BPK. The sampling technique used is purposive sampling (samples using criteria). The criteria in question, namely the availability of financial data, audit opinion data, and total population. Methods of data collection in this study is a documentation done by collecting data from books and publications, both online and offline.

\section{Research Model}

This study uses the one exogenous variables is fiscal decentralization, that is the authority and responsibility in the preparation, implementation and monitoring regional goverment budget by local governments. Measure of the degree of authority and 
responsibility given by central government to local government in exploring and managing income. Measurement of fiscal decentralization variables in this study using a ratio indicator between Own Source Revenue and tax revenues and non-tax with total regional expenditure (Badrudin, 2012: 49).

This study also used the endogenous intervening variable local government size, that is local government size is a nominal to describe the magnitude of a local governance (Kusumawardani, 2012). According to Manik (2013), local government size variable was measured by using a formula of revenue (central and regional) with total population. The dependent variable in this research is the local financial performance, that is measure of performance using financial indicators (Sularso and Restianto, 2011). The local financial performance can be measured by several ratios, among them effectiveness ratio, local financial independence ratio, and conformity ratio.

This study also uses a moderating variable is audit opinion, according to Law No. 15 Of 2004 on Management and Financial Responsibility State article 1 paragraph (11) opinion is a statement professional as conclusion examiner's regarding the level of fairness of the information presented in the financial statements. The results measurement audit opinion variable expressed in quantitative form in the following order: (1) Unqualified Opinion (UO), (2) Unqualified Opinion with Explanatory Language (UO-EL), (3) Qualified Opinion (QO), (4) Adverse Opinion (AO), and (5) Disclaimer Opinion (DO).

\section{Analysis Techniques}

The data analysis technique in this study use descriptive and inferential statistics analysis. Descriptive analysis is used to reveal a descriptive overview of the field data in a way to interpret the results of processing through the tabulation to describe the tendency of empirical data and descriptive as the average value. Inferential statistics analysis used to Partial Least Square (PLS) especially WarpPLS because WarpPLS also directly display the significant value of making it easier for researchers to immediately know the results. WarpPLS can give a warning if there multikolinearitas fairly high and the availability of the value output of the indirect/ mediation (Solihin dan Dwi, 2013: 32-35). As the panel regression approach in the research is the simplest because it combines data time series and cross section (Winarno, 2015:101). Decision-making hypothesis test used in this study is, if the significance value $<0.10$, then the hypothesis is accepted.

\section{RESULT AND DISCUSSION}

\section{Descriptive Statistics Analysis}

Table 1 below describes the characteristics of variables such minimum, maximum, and mean.

Based on Table 1 seemed variable fiscal decentralization at counties/cities in Lampung Province in 2010-2013 had an average of 0.1367 , meaning that the numbers of fiscal decentralization at counties/cities in Lampung Province is very low. Fiscal decentralization low of 0.0759 occurred in Tanggamus in 2013 because local revenues and revenue sharing of tax and non-tax are not comparable with the expenditure area. Consequently Tanggamus have a high dependence on the central government in order to earn additional income that regional spending needs can be met. Fiscal decentralization high of 0.8837 occurred in Mesuji in 2010. It is supported by the high local revenues and other income were legitimate. 
Fiscal Decentralization Effect on Financial Performance: ... (Eka Ningsih Puji Rahayu, Rudy Badrudin)

Table 1

Variable Description

\begin{tabular}{lccc}
\hline \multicolumn{1}{c}{ Variable } & Minimum & Maximum & Mean \\
\hline Fiscal Decentralization & 0.0759 & 0.8837 & 0.1367 \\
Effectiveness Ratio & 0.5505 & 54.8299 & 2.3796 \\
Ratio Local Financial Independence & 0.0100 & 0.5911 & 0.0556 \\
Conformity Ratio & 0.0867 & 0.5051 & 0.2458 \\
Local Government Size & 0.8234 & 4.0271 & 1.6679 \\
Audit Opinion & 1 & 5 & 2.52 \\
\hline
\end{tabular}

Source: Obtained from data processing.

Effectiveness ratio on the budget at counties/cities in Lampung Province in $2010-2013$ by an average of 2.3796 with effectiveness ratio was lowest in Way Kanan amounted to $55.05 \%$ in 2011. Way Kanan not managed to realize a local revenue. Effectiveness ratio was highest in Mesuji amounted to $5,483 \%$ in 2010 because it can exceed 100 percent. The ratio of local financial independence on the budget at counties/ cities in Lampung Province in 2010-2013 by an average of 0.0556 with local financial independence lowest in Tulang Bawang Barat amounted to 0.0100 in 2010. That is, Tulang Bawang Barat in 2010 was not able to finance all the needs of the region. The ratio of local financial independence was highest in Mesuji amounted to 0.5911 in 2010.

The ratio harmony public expenditures at the budget counties/cities in Lampung Province in 2010-2013 by an average of 0.2458 . That is, the counties/ cities government to allocate funds for development expenditures amounted to only $24.58 \%$ of the total budget. Harmony ratio was lowest in Lampung Tengah amounted to 0.0867 in 2010 and this ensures Lampung Tengah many concentrate on expenditures. The ratio of the highest harmony in Tulang Bawang amounted to 0.5051 in 2013. That is, Tulang Bawang in 2013 more priority to development expenditures.
The size of local government describes the large and the small size at the counties/ cities in Lampung Province. The larger the size of the government and thus further strengthen the counties/cities, because of the activities and responsibilities in the counties/cities will be more credible and reliable to meet the needs of the autonomous region. Variable size of the counties/cities in Lampung Province in 2010-2013 by an average of 1.6679. The size of government was lowest in Lampung Selatan amounted to 0.0867 in 2010 and the size of government was highsest occurred in Kota Metro amounted to 4.0271 in 2013. The situation in the two regions affected by PAD and population.

The audit opinion illustrates both the poor level of transparency and accountability in the financial statements of local government counties/cities in Lampung Province based on the results from BPK granting audit opinion. There are five audit opinion that is used by BPK to express an opinion, which is unqualified (WTP), unqualified with an explanatory paragraph, a qualified, the opinion is not fair, and Not Giving Opinions (TMP). Variable audit opinion on counties/ cities in Lampung Province in 2010-2013 had an average of 2.52. That is, the audit opinion of the counties/cities in Lampung Province is still in a bad zone. The audit opinion be one way to measure the success of the counties/ 
cities governments in managing local finance based on provisions of existing law.

\section{Inferential Statistics Analysis}

Evaluate the value of goodness of fit model serves to determine the suitability of a model used in this study by using a fiscal decentralization variable, local financial performance, local government size, and audit opinion. Results of testing the goodness of fit model can be seen in Table 2 below:

Tabel 2

Goodness of Fit Model Value

\begin{tabular}{cl}
\hline \multicolumn{1}{c}{ The Criteria } & \multicolumn{1}{c}{ Goodness of Fit Model } \\
\hline $\mathrm{APC}=0.289, \mathrm{P}<0.001$ & Good if $\mathrm{P}<0.05$ \\
$\mathrm{ARS}=0.494, \mathrm{P}=0.095$ & Good if $\mathrm{P}<0.05$ \\
$\mathrm{AVIF}=31.402$ & Good if $<5$ \\
\hline
\end{tabular}

Source: Obtained from data processing.

Based on the test results, the Average R-squared value (ARS) obtained the results of 0.494 with a value of $p=0,095$. This means the value of the ARS is not significant because it can be called significant if the $\mathrm{p}$-value of $<0.05$. Value 0.494 shows that the variables in this study are only able to affect the dependent variable amounted to $49.4 \%$ and $50.6 \%$ owned by other variables outside the model. Average Path Coefficient (APC) values of 0.289 with a value of $p$ $<0.001$. This means a significant APC values $(<0.05)$. The significant value of APC can prove that endogenous and exogenous variables have a cause and effect relationship either directly or indirectly. In addition, the high multicollinearity for the model in this study proved the high value of Average Variance Inflation Factor (AVIF) amounted to 31.402. Testing AVIF moderation should be the main focus for the WarpPLS using interactions between variables can occur multicollinearity (Sholihin and Dwi, 2013: 61). Multicollinearity on research is not caused by the moderating variable, because after deletion of data outliers, AVIF value of
$<0.05$. So it can be further analyzed.

The impact arising from non-fulfillment of the criteria of the value of goodness of fit model is a model be considered good, and the solution can be done by adding either an endogenous variable endogenous dependent or intervening. In addition, the lack of samples in this study can also make the cause of the poor value of goodness of fit model. The need for additional data, will be but this can not be done. This study uses data years 20102013, when adding data before the year 2010 there will be three districts which can not be excluded from the sample because of the newly-formed in 2008 and financial statement data become available each complete in 2010 . The principal purpose of research this is to see the implementation of regional autonomy under decentralization (there are three new districts in the era of regional autonomy), so the solution is to add the data in 2014, but such data are not available at this time, which should be obtained from early July in accordance with the mandate Law No. 17 of 2003 on State Finance of article 31 .

According Solihin and Dwi (2013: 61), interpretation of indicator depending on the model fit SEM analysis purposes. If the aim is only testing the hypothesized relationship among other variables, the indicator model fit is becoming less important. The main objective in this study was not to compare some of the best models, just test the hypothesis only, then no replacement models.

Based on the results of statistical tests fiscal decentralization on regional financial performance showed that the value of the path coefficient have positive value 0.93 and a p-value of 0.08 or less than the standard specified p-value $(<0.10)$. Based on these test results can be concluded that the first hypotheses in this study received, fiscal decentralization significant positive effect on the financial performance of the counties/ cities in Lampung Province. 
Fiscal Decentralization Effect on Financial Performance: ... (Eka Ningsih Puji Rahayu, Rudy Badrudin)

Table 3

Results of Hypotheses Testing

\begin{tabular}{cllll}
\hline No & Relationship Variable & \multicolumn{1}{c}{ PathCoefficient } & P-Value & Conclusion \\
\hline 1 & Fiscal ---> Perform & 0.93 & 0.08 & Supported \\
2 & Fiscal ---> Size & -0.13 & 0.35 & Rejected \\
3 & Size ---> Perform & 0.05 & 0.43 & Rejected \\
4 & Fiscal*AO ---> Perform & 0.05 & 0.40 & Rejected \\
\hline
\end{tabular}

Source: Obtained from data processing.

This suggests that increasing fiscal decentralization proxied with counties own source revenue and revenue sharing fund and non-tax to local expenditure total will take effect good on more increasing local financial performance for budgeting counties own source revenue at once the realization that, so will affect financial independence local on the counties/cities in Lampung Province which will ultimately impact both on the conformity expenditure local. Compatibility setting shopping area, because the role of fiscal decentralization improve reception area, so that local governments will be more easily manage the realization of counties/ cities own source revenue and expenditure arrangements. These findings support the results of a study Halim and Abdullah (2006), Sianturi et al. (2013), and Susanto and Badrudin (2016).

This research is evidence that the implementation of regional autonomy, especially in the fiscal sector was able to improve the financial performance of the counties/cities in Lampung Province, especially the success in realizing counties/ cities own source revenue. Budgeting strategy that do the counties/cities in Lampung Province be a sign of that countiess/ cities in Lampung Province not arbitrarily in predicting the realization of counties/ cities own source revenue based on the real potential that exists. Although the counties/ cities in Lampung Province have not managed to achieve financial independence that led to dependence on the central government is still very high. In addition to the counties/cities governments have not managed to organize and prioritize portion routine expenditure and development expenditure.

Based on the statistical test fiscal decentralization on local government size, shows that the value of the path coefficients have are negative values of -0.13 and a $p$-value of 0.35 or greater than the standard specified $\mathrm{p}$-value $(<0.10)$. The coefficient negative sign indicates that if the implementation of fiscal decentralization has been optimal it will have a bad impact on local goverment size. Based on these test results can be concluded that the second hypotheses in this study was rejected, namely fiscal decentralization significant negative effect on the local government size in the countiess/cities in Lampung Province. These findings does not support the study results Dwijayanti and Rusherlistyanti (2013).

This suggests that fiscal decentralization is proxied with counties own source revenue and revenue sharing fund tax and non-tax to expenditure local total expenditures would bring the negative effect on the size of local government proxied with revenue (central and local) of the total population. This is caused by the entire delegation of authority to local government, but local government have has not been able to carry it. Evident from the pattern of relationships instructive owned by the counties/cities in Lampung Province, so that the greater fiscal decentralization that would make the size of local government becomes increasingly lower. In addition, greater fiscal decentralization are becoming 
much chance for diversion of funds as more and more funds become increasingly unmanageable, as well as the demand meet the needs of growth population accompanied by a growing total population.

Based on the results of statistical tests the government local size on local financial performance, shows that the value of the path coefficient is positive value 0.05 and a $\mathrm{p}$-value of 0.43 or greater than the standard specified p-value $(<0.10)$. Marked positive coefficient indicates that increasing the local government size will the higher the local financial performance. Based on these test results can be concluded that the third hypotheses in this study was rejected, local government size is not a significant positive effect on the local financial performance the counties/cities in Lampung Province. These findings does not support the study results Kusumawardani (2012), Fidelius (2013), Malik (2013), and Badrudin (2015).

This shows that the local government size proxied by revenue (central and local) population has not been able to provide a positivecontributiontoimproving thefinancial local financial performance. Although local government size in the countiess/cities were small because of the imbalance of population increase should be financed with a total income of less than optimal. Though the size of a large regional government can have a positive impact also for budgeting and the realization counties own source revenue and counties own source revenue higher would be capital to regional financial independence that will create the physical development of the area which will indirectly help boost economic growth, because the large size of local government likely to encourage local financial performance. Meaning that more funds can be used to meet the needs of the public (Smeru, 2002:41).

Based on the results of statistical tests fiscal decentralization on regional financial performance with the audit opinion as moderating variables showed that the value of the path coefficient is positive value 0.05 and a p-value of 0.40 or greater than the standard specified $p$-value $(<0: 05)$. Marked positive coefficient indicates that the better the audit opinion (unqualified opinion) obtained an area it will reinforce the positive effects of fiscal decentralization on the local financial performance the counties/cities in Lampung Province. Based on these test results can be concluded that the fourth hypotheses in this study was rejected, namely fiscal decentralization is not a significant positive effect to the local financial performance with audit opinion as moderating variable in the counties/cities in Lampung Province. This is evident from not optimal financial management in local government at the counties/cities in Lampung Province so many counties/cities in Lampung Province in the year 2010-2013 were getting bad audit opinion (unqualified opinion with explanatory language, qualified opinion, adverse opinion, and disclaimer opinion) from BPK. These findings does not support the study results Basrie et al. (2012).

\section{CONCLUSION AND RECOMMENDA- TION}

\section{Conclusions}

Fiscal decentralization has significant positive effect on regional financial performance. Although still low of fiscal decentralization value and still shows the relations that instructive, but the fiscal decentralization low can be categorized on target, because through the delegation of authority fiscal made the government is able to perform financial management although there is not yet local financial independence full and the setting local expenditure proportion not yet inadequate. Fiscal decentralization has significant negative effect on local governance size, because regional autonomy is a sign that the local government is not only 
given confidence to dig and manage potentials in the autonomous region but also to be fully able to finance all the public interest, while acquired is not optimal to finance the interest of the population in the autonomous region although there are additional revenues from the center so as to make the size of government becomes increasingly lower. Local government size is not a significant positive effect on the regional financial performance. This means the size of a small government is not able to increase local financial performance. The small effects the local government size to local financial performance due to the increasingly rapid population growth is not matched by the rapid amount of income, especially local income, so causing the local government size has little influence. The counties/cities that have small counties/cities own source revenue and the much as total population will cause the local government size can not as much expected due to a restriction of transfer funds given by the central government. As a result, government size is not the maximum would also hamper the local financial performance. Fiscal decentralization has not significant positive effect on the local financial performance with audit opinion as moderating variables. It is meaningful audit opinion has not been able to strengthen positive effect fiscal decentralization on local financial performance. The small effect of audit opinions on the positive effects of fiscal decentralization on regional financial performance is consequence from still bad from BPK audit opinion received by the counties/cities in Lampung Province. So can be ascertained most of the number in the financial statements is not the actual number. Still need to evaluate the performance of human resources in each counties/cities is also a consideration for the government that the implementation of regional autonomy may also running as it should, because it will feel useless if the result of hard work in earned income that will be used to finance the autonomous region abused by the parties are not responsible.

This research has evidence that audit opinion does not make fiscal decentralization stronger in counties/cities Lampung Province. There are several factors that cause. The institutional structure of the government counties/cities and province in Lampung Province requires further evaluation due to low quality and quantity of employees and there are overlapping authority between counties/cities and province. Routine expenditures (personnel expenditure) in the counties/cities Lampung Province tends to increase while capital expenditure tends to decrease. This results in low capital expenditure for infrastructure development. The size of fiscal decentralization in counties/ cities Lampung Province low due to the local revenue and tax revenue-sharing and non-tax low while the relatively high budget. This is due to lack of personnel able to be creative in raising local revenue due to limited human resources. In fact, the balance of funds from the central government also allocated for routine expenditure (personnel expenditure). The size of the fiscal decentralization in cities is higher than counties have an impact on the ability to build infrastructure so that infrastructure development in cities is relatively more developed than counties. In addition, the cities government budget financial performance was also better than the counties in Lampung Province.

\section{Research Limitations}

The variables this study have not been up to affect the financial performance of it is known from the low value of R-Square, so need to add another variable that can improve local financial performance such as economic growth because economic growth is an important factor also in support to improve of local financial performance. The higher and faster economic growth it will be easier for a counties/cities in improving 
local financial performance. In addition, it can add a asset variable because the large asset will be easier for the government in the realization of postal counties own source revenue. The law is to earn a great income, necessary facilities must complete/good too and the need to provide necessary facilities as well as adequate cost. This research is aim to know the implementation of regional autonomy overall in Lampung Provinsi, so unknown among counties/cities are capable of implementing regional autonomy. So if this research be distinguished the economic strength of each counties/city in Lampung Province, the research result is robust.

\section{Suggestions}

Based on the conclusions generated in this study, it submitted several suggestions are expected to be useful for practical purposes and further research. The government needs to pay attention to financial governance, for example pay attention to the routine and development expenditure for the acceleration of economic growth of Lampung Province is a province that is strategically located as a gateway to the island of Sumatra, so user facilities such as cross road Sumatera be convenient. Maximizing counties/cities own source revenue so that can to manage and improve the resources that already exist or excellence of each region like the beach, the harbor and the hills that can be used as a tourism needs to be given a public facility that will provide comfort for visitors in the end will also be able to add local retribution, increase the size of the postal levies, as well as improving economic growth in the surrounding community, so it will be able to help the welfare of society. Based on the results of the audit opinion received on counties/cities in Lampung Province, the government needs to make audit opinion improvements as evidence that the local government financial statements have been presented in a transparant and accountable. For further research, should include Klassen typology analysis to distinguish the economic strength of each counties/city in Lampung Province so will result robust research.

\section{REFERENCES}

Badrudin, Rudy. 2017. Ekonomika Otonomi Daerah. UPP STIM YKPN, Yogyakarta.

Badrudin, Rudy. 2015. Evaluation of The Specific Allocation Fund for Indonesian Society Welfare. International Journal of Applied Business and Economic Research. Vol. 13, No. 7: 56075624, viewed 9 December 2017, http://www.serialsjournals.com/ serialjournalmanager/pdf/14577691 78.pdf.

Badrudin, Rudy and Baldric Siregar. 2015. The Evaluation of The Implementation of Regional Autonomy in Indonesia. Economic Journal of Emerging Markets. Vol 7, No. 1: 1-11, viewed 9 December 2017, http://journal. uii.ac.id/ index.php/ JEP/article/ view/4257.

Basrie, Hassan, Yashinta Arly, and Riswan. 2012 Analisis Laporan Keuangan Dikaitkan dengan Kinerja Pemerintah Daerah Kota Bandar Lampung. Jurnal Akuntansi \& Keuangan. Vol. 3, No. 1: 19-31.

Dwijayanti, Retno and Rusherlistyanti. 2013. Analisis Perbandingan Kinerja Keuangan Pemerintah Propinsi se Indonesia. Jurnal Ekonomi dan Bisnis. Vol. 12, No. 1: 46-64.

Fidelius. 2013. Analisis Rasio untuk Mengukur Kinerja Pengelolaan Keuangan Daerah Kota Manado. Jurnal Ekonomi, Manajemen, Bisnis, dan Akuntansi. Vol. 1, No. 4: 61-82.

Halim, Abdul and Syukriy Abdullah. 2006. Hubungan dan Masalah Keagenan di 
Pemerintah Daerah: Sebuah Peluang Penelitian Anggaran dan Akuntansi. Jurnal Akuntansi Pemerintahan. Vol. 2, No. 1: 53-64.

Kusumawardani. 2012. Pengaruh Size, Kemakmuran, Ukuran Legislatif, Leverage terhadap Kinerja Keuangan Pemerintah Daerah di Indonesia. Accounting Analysis Journal. Vol. 1, No. 1: 21-35.

Manik, Tumpal. 2013. Analisis Pengaruh Kemakmuran, Ukuran Pemerintah Daerah, Inflasi, Intergovernmental Revenue dan Kemiskinan terhadap Pembangunan Manusia dan Pekonomian. Jurnal Organisasi dan Manajemen. Vol. 9, No. 2: 107-124.

Sianturi, Anastasia, Sjamsiar Sjamsuddin, and Tjahjanulin Domai. 2013. Peran Pendapatan Asli Daerah dalam Menunjang Desentralisasi Fiskal dan Pembangunan Daerah (Studi pada Dinas Pendapatan Kota Batu). Jurnal Administrasi Publik. Vol. 2, No. 3: 557-563.

Siregar, Baldric and Rudy Badrudin, 2017, "Degree of Fiscal Decentralization and Flypaper Effect: Evidence from
Indonesia", Advanced Science Letters, 23(9), 9013-9019. DOI: https://doi. org/10.1166/asl.2017.10014.

Smeru. 2002. Dampak Desentralisasi dan Otonomi Daerah atas Kinerja Pelayanan Publik: Kasus Kota Bandar Lampung Provinsi Lampung. Lembaga Penelitian Smeru, AusAID, dan Ford Foundation.

Solihin, Mahfud and Dwi Ratmono. 2013. Analisis SEM-PLS dengan WarpPLS 3.0. Andi Offset. Yogyakarta.

Sularso and Restianto. 2011. Pengaruh Kinerja Keuangan terhadap Alokasi Belanja Modal dan Pertumbuhan Ekonomi Kabupaten/Kota di Jawa Barat. Media Riset Akuntansi. Vol. 1, No. 2: 96-116.

Susanto, Djoko and Rudy Badrudin. 2016. Budgeting Politic for Supporting Competitive Industry Sector. International Journal of Business and Commerce. Vol. 5, No. 6: 49-64.

Winarno, Wing Wahyu. 2015. Analisis Ekonometrika dan Statistika dengan EViews. Edisi 4. UPP STIM YKPN. Yogyakarta.

\section{APPENDIX}

Table 4. The Data of Research Variables

\begin{tabular}{ccccccc}
\hline No. & $\begin{array}{c}\text { Fiscal } \\
\text { Desentralization }\end{array}$ & $\begin{array}{c}\text { Local Government } \\
\text { Size }\end{array}$ & $\begin{array}{c}\text { Audit } \\
\text { Opinion }\end{array}$ & $\begin{array}{c}\text { Effectivity } \\
\text { Ratio }\end{array}$ & $\begin{array}{c}\text { Local Finantial } \\
\text { Independent } \\
\text { Ratio }\end{array}$ & $\begin{array}{c}\text { Conformity } \\
\text { Ratio }\end{array}$ \\
\hline 1 & 0.1415 & 0.9164 & 3 & 1.1411 & 0.0346 & 0.0867 \\
2 & 0.0977 & 1.0747 & 3 & 1.3420 & 0.0398 & 0.1574 \\
3 & 0.1297 & 1.2669 & 5 & 2.3072 & 0.0669 & 0.1863 \\
4 & 0.0952 & 1.3286 & 3 & 1.2510 & 0.0507 & 0.1855 \\
5 & 0.1297 & 0.8234 & 5 & 1.0918 & 0.0527 & 0.1114 \\
6 & 0.1290 & 1.0953 & 4 & 1.1711 & 0.0680 & 0.1528 \\
7 & 0.1217 & 1.2108 & 3 & 1.3638 & 0.0713 & 0.2465 \\
8 & 0.1322 & 1.2608 & 3 & 1.3509 & 0.0835 & 0.1934 \\
9 & 0.0923 & 1.2968 & 1 & 0.9154 & 0.0178 & 0.2189 \\
10 & 0.0934 & 1.5497 & 3 & 2.3840 & 0.0314 & 0.1954 \\
11 & 0.0797 & 1.6608 & 2 & 1.5789 & 0.0216 & 0.1925 \\
12 & 0.0830 & 1.8609 & 2 & 2.3193 & 0.0367 & 0.3911 \\
\hline
\end{tabular}




\begin{tabular}{|c|c|c|c|c|c|c|}
\hline No. & $\begin{array}{c}\text { Fiscal } \\
\text { Desentralization }\end{array}$ & $\begin{array}{c}\text { Local Government } \\
\text { Size }\end{array}$ & $\begin{array}{c}\text { Audit } \\
\text { Opinion }\end{array}$ & $\begin{array}{l}\text { Effectivity } \\
\text { Ratio }\end{array}$ & $\begin{array}{c}\text { Local Finantial } \\
\text { Independent } \\
\text { Ratio }\end{array}$ & $\begin{array}{c}\text { Conformity } \\
\text { Ratio }\end{array}$ \\
\hline 13 & 0.1997 & 1.0876 & 5 & 1.1554 & 0.0904 & 0.3003 \\
\hline 14 & 0.2126 & 1.3326 & 4 & 1.3793 & 0.1371 & 0.0953 \\
\hline 15 & 0.2646 & 1.6165 & 5 & 1.2935 & 0.2047 & 0.2006 \\
\hline 16 & 0.2382 & 1.7924 & 5 & 0.9642 & 0.2136 & 0.2245 \\
\hline 17 & 0.1079 & 1.4137 & 5 & 1.2457 & 0.0274 & 0.2888 \\
\hline 18 & 0.1047 & 1.6291 & 4 & 1.4145 & 0.0312 & 0.2377 \\
\hline 19 & 0.1046 & 1.7691 & 5 & 1.7641 & 0.0334 & 0.2366 \\
\hline 20 & 0.0940 & 1.9661 & 5 & 1.1859 & 0.0396 & 0.4698 \\
\hline 21 & 0.1602 & 1.1468 & 3 & 3.5717 & 0.0494 & 0.2431 \\
\hline 22 & 0.1091 & 1.6550 & 3 & 0.8903 & 0.0300 & 0.2573 \\
\hline 23 & 0.1069 & 1.5914 & 3 & 0.9186 & 0.0354 & 0.1978 \\
\hline 24 & 0.1358 & 1.6478 & 3 & 1.3174 & 0.0526 & 0.5051 \\
\hline 25 & 0.1406 & 0.8842 & 3 & 1.3284 & 0.0100 & 0.2428 \\
\hline 26 & 0.0904 & 1.8951 & 5 & 2.0114 & 0.0103 & 0.3661 \\
\hline 27 & 0.0932 & 2.0338 & 5 & 1.1019 & 0.0112 & 0.3465 \\
\hline 28 & 0.0794 & 2.1884 & 5 & 1.3537 & 0.0182 & 0.3249 \\
\hline 29 & 0.1336 & 1.1795 & 5 & 0.5606 & 0.0183 & 0.2049 \\
\hline 30 & 0.1086 & 1.5079 & 5 & 0.5505 & 0.0153 & 0.1916 \\
\hline 31 & 0.1097 & 1.6786 & 5 & 0.7467 & 0.0146 & 0.2010 \\
\hline 32 & 0.0981 & 1.8394 & 5 & 1.5609 & 0.0319 & 0.2662 \\
\hline 33 & 0.1798 & 0.9468 & 1 & 1.0335 & 0.0229 & 0.1372 \\
\hline 34 & 0.1818 & 1.1363 & 1 & 1.5692 & 0.0287 & 0.3119 \\
\hline 35 & 0.1748 & 1.2662 & 3 & 1.9620 & 0.0403 & 0.1506 \\
\hline 36 & 0.1360 & 1.3830 & 3 & 1.0053 & 0.0296 & 0.1539 \\
\hline 37 & 0.1644 & 2.9319 & 5 & 1.0953 & 0.0647 & 0.1923 \\
\hline 38 & 0.1638 & 3.4935 & 5 & 1.4674 & 0.0818 & 0.2349 \\
\hline 39 & 0.1886 & 3.6891 & 5 & 1.4768 & 0.0878 & 0.1443 \\
\hline 40 & 0.1861 & 4.0271 & 5 & 1.3979 & 0.1181 & 0.1714 \\
\hline 41 & 0.1041 & 1.2876 & 3 & 2.6255 & 0.0258 & 0.2158 \\
\hline 42 & 0.0978 & 1.3587 & 3 & 2.1112 & 0.0327 & 0.4711 \\
\hline 43 & 0.0986 & 1.6598 & 3 & 1.7471 & 0.0380 & 0.2898 \\
\hline 44 & 0.0767 & 1.8793 & 3 & 1.4208 & 0.0329 & 0.2918 \\
\hline 45 & 0.0852 & 1.0414 & 1 & 1.2037 & 0.0153 & 0.1495 \\
\hline 46 & 0.0899 & 1.6560 & 3 & 1.1183 & 0.0318 & 0.1834 \\
\hline 47 & 0.0916 & 1.9949 & 1 & 1.3274 & 0.0394 & 0.4413 \\
\hline 48 & 0.0849 & 2.0688 & 3 & 1.2177 & 0.0388 & 0.2147 \\
\hline 49 & 0.0977 & 1.1266 & 3 & 1.1571 & 0.0193 & 0.1617 \\
\hline 50 & 0.0913 & 1.3926 & 3 & 1.2388 & 0.0214 & 0.1951 \\
\hline 51 & 0.0850 & 1.5069 & 3 & 1.2959 & 0.0226 & 0.2084 \\
\hline 52 & 0.0759 & 1.5774 & 3 & 1.1009 & 0.0249 & 0.2523 \\
\hline 53 & 0.8837 & 1.4557 & 3 & 54.8299 & 0.5911 & 0.3626 \\
\hline 54 & 0.0843 & 2.5193 & 1 & 2.1998 & 0.0113 & 0.4497 \\
\hline 55 & 0.1181 & 2.3329 & 3 & 1.8017 & 0.0185 & 0.3487 \\
\hline 56 & 0.1011 & 2.4722 & 3 & 1.3224 & 0.0261 & 0.3151 \\
\hline
\end{tabular}

Source: Obtained from data processing. 